\title{
Spectrofluorimetric determination of benidipine in pharmaceutical preparation and spiked plasma samples using 7-fluoro-4-nitrobenzo-2-oxa-1,3-diazole
}

\author{
Cem ÖNAL 1 * (D) , Şerife Evrim KEPEKÇİ TEKKELİ 2 (D) \\ 1 Abdi İbrahim Pharmaceuticals, Hadımköy, İstanbul. \\ 2 Faculty of Pharmacy, Department of Analytical Chemistry, Bezmialem Vakıf University, Fatih, İstanbul, Turkey \\ * Corresponding Author. E-mail: cemfox@yahoo.com (C.Ö.); Tel. +90 2126226819.
}

Received: 30 April 2019 / Revised: 14 June 2019 / Accepted: 05 August 2019

ABSTRACT: A new spectrofluorimetric technique was produced for the analysis of benidipine (BDP) in tablets and spiked plasma samples. The developed method was based on coupling between Benidipine, (a secondary amine group), and 7-fluoro-4-nitrobenzo-2-oxa-1,3-diazole (NBD-F) forming fluorescent dervatived as a NBD-Benidipine. The reaction was occured by using $\mathrm{pH} 8.5$ buffer solution to form fluorescent derivatives that are measured $\lambda_{\text {em: }}: 550 \mathrm{~nm}$ and $\lambda_{\text {ex }}: 465$ $\mathrm{nm}$. A variable parameters effecting on the derivatization process were studied. The calibration graph was linear in the range of $10-200 \mathrm{ng} \mathrm{mL}^{-1}$. LOD and LOQ values were a $0.445 \mathrm{ng} \mathrm{mL}^{-1}$ and $1.348 \mathrm{ng} \mathrm{mL}^{-1}$, respectivelly. The developed method was applied to BDP in commercially available film tablets. An average recovery was found as $99.80 \%$ without interference from the available excipients. Besides, the fluorimetric technique was also succesfully applied to spiked human plasma.

KEYWORDS: Benidipine; 7-fluoro-4-nitrobenzofurazan; spectrofluorimetry; pharmaceutical preparations; human plasma.

\section{INTRODUCTION}

Calcium antagonist group drugs are very frequently used cardiovascular drugs [1]. $( \pm)-\left(R^{*}\right)-2,6-$ Dimethyl-4-(m-nitrophenyl)-1,4-dihydropyridine-3,5-dicarboxylic acid $\left(R^{*}\right)-1$-benzyl-3-piperidinyl ester, methyl ester hydrochloride (benidipine hydrochloride) (Figure 1) is often used as an anti anginal and antihypertensive agent. Treatment may be administered daily for hypertension at a 4 or $8 \mathrm{mg}$ single dose or twice a day $[2,3]$. In a study on volunteers receiving a $16 \mathrm{mg}$ of oral benidipine tablet, $C_{\max }$ value was found as $10.54 \pm 6.02 \mathrm{ng} \mathrm{mL}^{-1}[4]$.<smiles>COC(=O)C1=C(C)NC(C)=C(C(=O)OC2CCCN(Cc3ccccc3)C2)C1c1cccc([N+](=O)[O-])c1</smiles>

Figure 1. Chemical structure of benidipine.

Literature research has been shown in a couple of methods for determination of BDP such as spectrophotometric [5] voltammetric and HPLC [6] gas chromatographic [7-9] and LC-MS methods [10]. The purpose of the present method is to develop a novel spectrofluorimetric method based on the reaction between benidipine and 7-fluoro-4-nitrobenzo-2-oxa-1,3-diazole (NBD-F) reagent. Amines react with NBD-F reagent to perform the fluorescent products with excitation at $460-470 \mathrm{~nm}$ and emission at 525-530 nm [11]. The developed study is a very sensitive fluorimetric technique for the analysis of BDP in tablets and spiked plasma samples. 


\section{RESULTS AND DISCUSSION}

BDP containes a secondary amino group which is easily reacting with NBD-F to produce a yellowcolored fluorescence in alkaline medium. The resulting derivative exhibits the highest fluorescence intensities by excitation at $465 \mathrm{~nm}$ and emmission at $550 \mathrm{~nm}$ in dichloromethane (Figure 2).

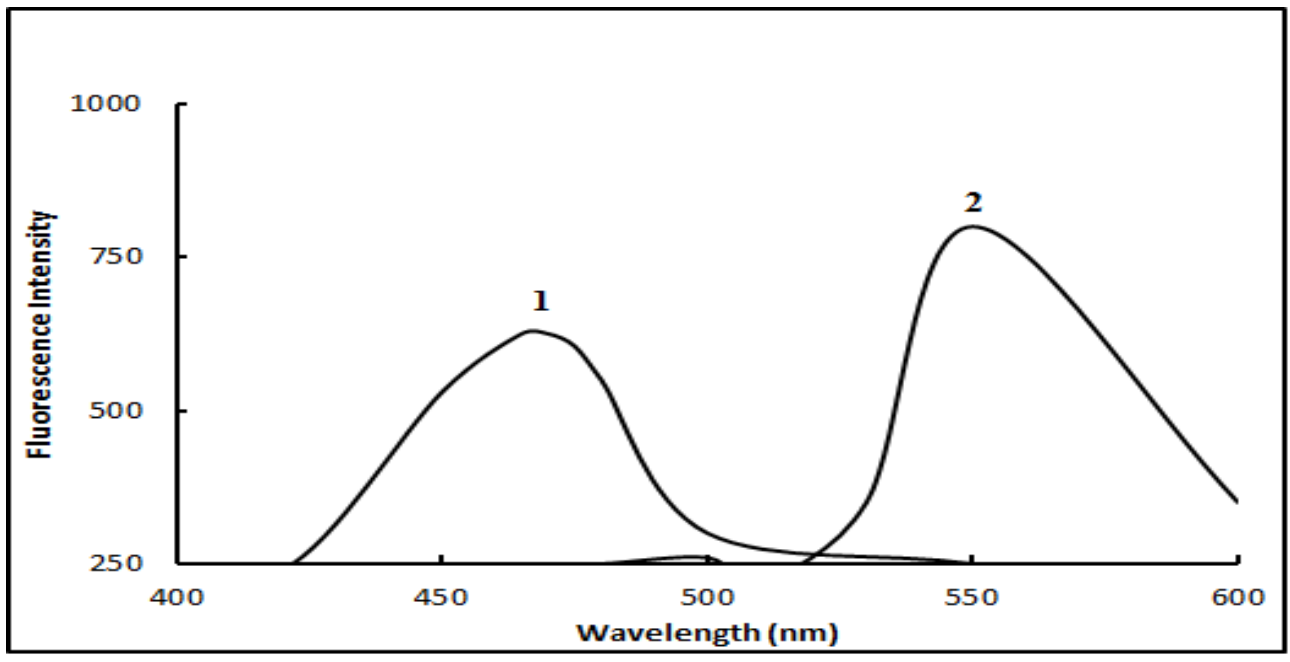

Figure 2. Fluorescence spectrum of the derivatization product of BDP with NBD-F: (1) Excitation spectrum and (2) Emission spectrum.

The experimental parameters have been investigated and optimized for the efficiency of the reaction product. Each parameter has been changed separately while the other parameters were constant. These parameters are as follows; diluting solvent, volume of the buffer, $\mathrm{pH}$, reaction time, concentration of NBD-F and temperature.

In order to choose optimum $\mathrm{pH}$, different $\mathrm{pH}$ values between 7 to 11 were studied using borate buffer. $\mathrm{pH} 8.5$ was choosen as optimum $\mathrm{pH}$ (Figure 3). Before measurement, the acidification was made with $0.2 \mathrm{~mL}$ of $1.0 \mathrm{~N} \mathrm{HCl}$ because of produce of NBD-OH (its maximum absorbance at $465 \mathrm{~nm}$ ). $0-3 \mathrm{~mL}$ volumes of $\mathrm{pH} 8.5$ borate buffer were trialed. $0.2 \mathrm{~mL}$ borate buffer addition is found to be suitable.

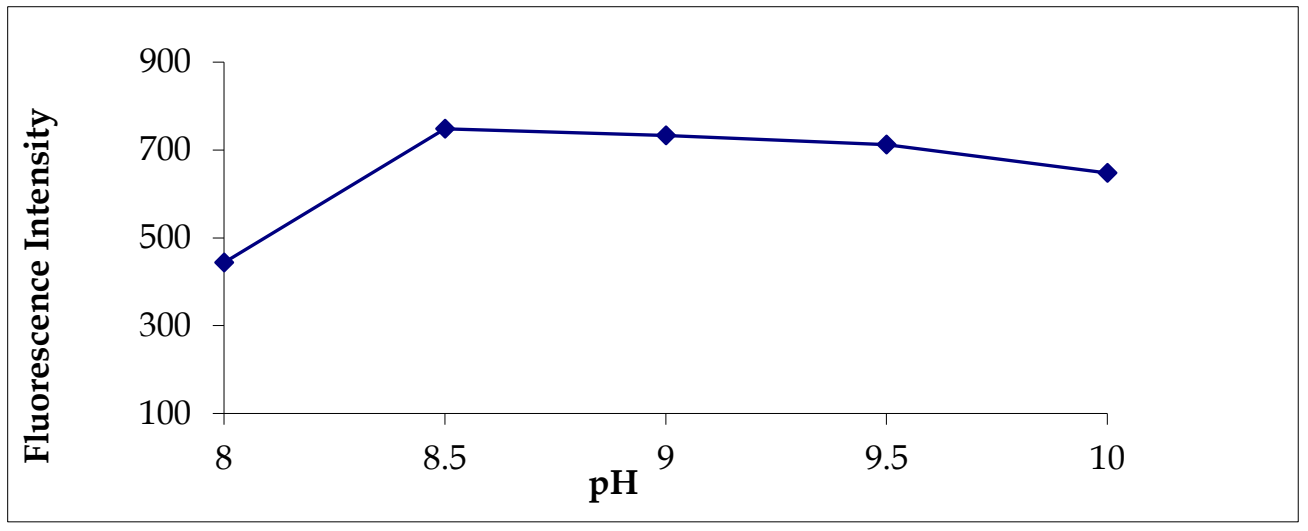

Figure 3. The results of $\mathrm{pH}$ studies on the derivatization process between BDP with NBD-F.

Temperature from 60 to $80^{\circ} \mathrm{C}$ range was investigated to found optimum temperature on the reaction procedure. the highest intensity obtained at $80^{\circ} \mathrm{C}$ (Figure 4). As shown in Figure 4, the temperature on the BDP and NBD-F reaction was examined at a range of 60 to $80^{\circ} \mathrm{C}$ and the highest intensity was obtained at $80^{\circ} \mathrm{C}$ at $3 \mathrm{~min}$. The obtained colour remained stable for $12 \mathrm{~h}$. 


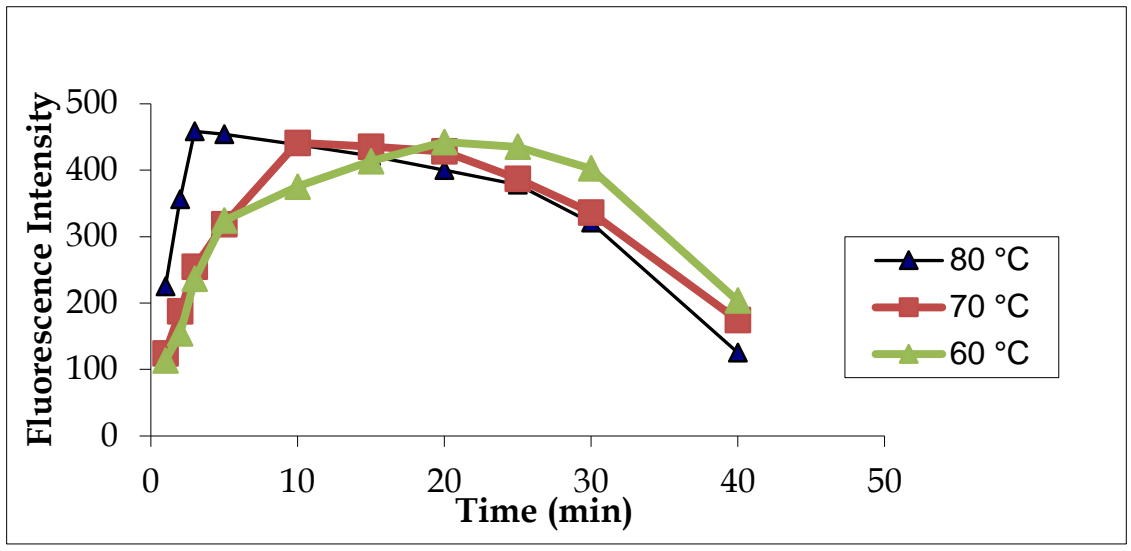

Figure 4. The optimum temperature and heating time selection.

The NBD-F concentration has been also invesitigated. As shown in Figure 5, $0.2 \mathrm{~mL}$ of $0.5 \%$ NBD-F solution was choosen. Organic solvents, (i.e. dichloromethane, acetonitrile, methanol, chloroform and ethyl acetate) were studied. Dichloromethane gave the highest absorbance.

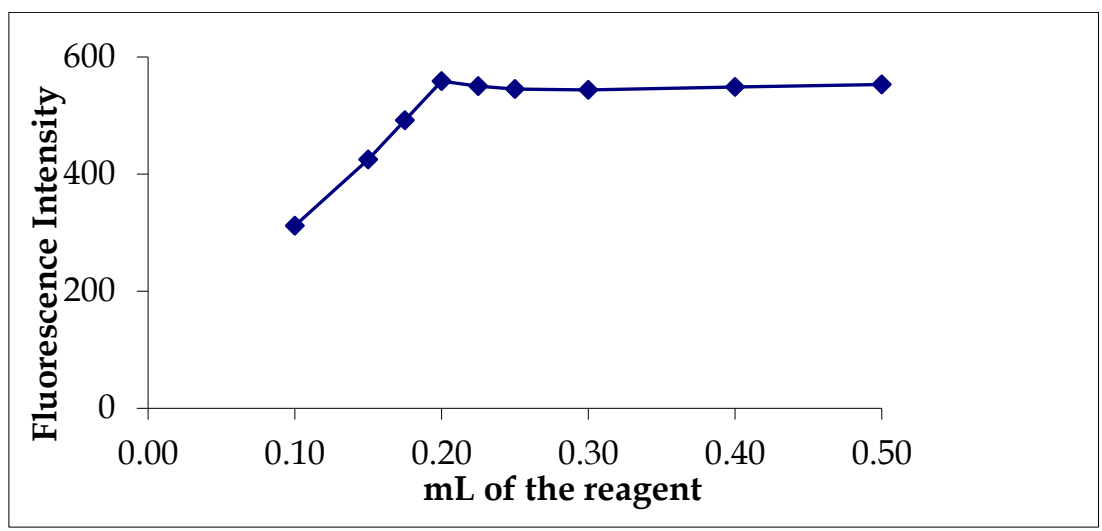

Figure 5. The results of volume of NBD-F on the derivatization process between BDP with NBD-F.

Different solvents for selecting the most suitable one for dilution were invesitaigated such as; methanol, acetonitrile, ethanol and acetone. Methanol gave best results. The molar ratio of NBD-F to BDP was investigated based on the continuous variation method of Job [12]. The reaction stoichiometry was obtained to be 1:1 ratio using equimolar solutions of BDP and NBD-F approving that one molecule of BDP reacts with one molecule of NBD-F (Figure 6).<smiles>COC(=O)C1=C(C)NC(C)=C(C(=O)OC2CCCN(Cc3ccccc3)C2)C1c1cccc([N+](=O)[O-])c1</smiles>

Benidipine<smiles>O=[N+]([O-])c1ccc(F)c2nonc12</smiles><smiles>COC(=O)C1=C(C)N(c2ccc([N+](=O)[O-])c3nonc23)C(C)=C(C(=O)OC2CCCN(Cc3ccccc3)C2)C1c1cccc([N+](=O)[O-])c1</smiles>

NBD-F 
Method validation has been performed according to linearity, accuracy, precision and robustness parameters (followings ICH recommendations) [13].

The calibration curves were plotted the relative fluorescence intensities against the drug concentrations (ng $\mathrm{mL}^{-1}$ ). The analytical parameters of the technique were presented at Table 1 . The relative fluorescence intensity values and the drug concentrations were linear within the range of $10-200 \mathrm{ng} \mathrm{mL}^{-1}$. The regression equation has been shown as:

$$
I_{\mathrm{f}}=4.4465 \mathrm{C}+102\left(r^{2}=0.9974\right)
$$

Where $\mathrm{I}_{\mathrm{f}}$ is the fluorescence intensity, $\mathrm{C}$ is the concentration of the drug in $\mathrm{ng} \mathrm{mL}-1$ and $r^{2}$ is the coefficient of determination $(n=5)$.

Table 1. The analytical parameters.

\begin{tabular}{|c|c|}
\hline Parameters & Values Found \\
\hline Wavelength (nm) & 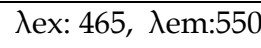 \\
\hline Concentration range ${ }^{\mathrm{a}}\left(\mathrm{ng} \mathrm{mL}^{-1}\right)$ & $10-200$ \\
\hline Regression equation & $I_{\mathrm{f}}=4.4465 \mathrm{C}+102$ \\
\hline Intercept \pm SD & $102 \pm 0.59$ \\
\hline Slope \pm SD & $4.4465 \pm 0.041$ \\
\hline Determination coefficient $\left(\mathrm{r}^{2}\right)$ & 0.9974 \\
\hline \multicolumn{2}{|l|}{ Precision } \\
\hline Intra-day a, RSD \% & 0.87 \\
\hline Inter-dayb, RSD \% & 1.25 \\
\hline LOD $\left(\mathrm{ng} \mathrm{mL}^{-1}\right)$ & 0.445 \\
\hline LOQ (ng mL $\left.{ }^{-1}\right)$ & 1.348 \\
\hline
\end{tabular}

The LOQ and LOD were measured following formula (according to ICH Q2 (R1) recommendation [13], The formula has been shown as;

$$
\mathrm{LOD}=3.3 \mathrm{Sa} / \text { slope } \quad \mathrm{LOQ}=10 \mathrm{Sa} / \text { slope }
$$

where Sa is the standard deviation of the intercept. LOD was $0.4451 .348 \mathrm{ng} \mathrm{mL}^{-1}$ and LOQ was $1.348 \mathrm{ng} \mathrm{mL}^{-1}$.

The precisions trials were performed by analysis of BDP at the three diffent concentrations $(20,100$, $200 \mathrm{ng} \mathrm{mL}^{-1}$ ) (each $\mathrm{n}=5$ ) for five consecutive days. The RSD values were found as $0.87 \%$, for intra-day precision and $1.25 \%$, inter-day precision that was indicated to high precision. (Table 1).

The standard addition technique was used for proving accuracy of the method. The $20 \mathrm{ng} \mathrm{mL}^{-1}$ of sample solution were added to $10,100,150 \mathrm{ng} \mathrm{mL}^{-1}$ concentration of the standard solution and analyzed. The results of recovery study were given in Table 2 . The mean recoveries were found as $99.80 \%$.

\begin{tabular}{|c|c|c|c|c|}
\hline $\begin{array}{l}\text { Amount taken }{ }^{\mathrm{a}} \\
\quad(\text { ng mL-1) }\end{array}$ & $\begin{array}{l}\text { Amount } \\
\text { added } \\
\left(\mathrm{ng} \mathrm{mL}^{-1}\right)\end{array}$ & $\begin{array}{c}\text { Total amount found }{ }^{b}\left(\mathrm{ng} \mathrm{mL}^{-1}\right) \\
\left(\text { Mean } \pm \text { S.D. } .^{\mathrm{c}}\right)\end{array}$ & Recovery (\%) & RSD (\%) \\
\hline \multirow{3}{*}{20} & 10 & $29.92 \pm 0.12$ & 99.20 & 0.40 \\
\hline & 100 & $120.05 \pm 0.85$ & 100.05 & 0.71 \\
\hline & 150 & $170.24 \pm 1.15$ & 100.16 & 0.68 \\
\hline
\end{tabular}

Table 2 . The recovery results.

Robustness was tested by measuring the effect of little modifications. In this research, one parameter was modified whereas the other was kept constant (time (optimum $\pm 1 \mathrm{~min}$ ), temperature (optimum $\pm 1^{\circ} \mathrm{C}$ ), 
$\mathrm{pH}$ (optimum \pm 0.1 ), and $\mathrm{HCl}$ concentration (optimum $\pm 5 \mathrm{mM}$ )) and the recovery percentage was measured. Obtained data proved the robustness of the proposed method.

The applicability of the proposed method was analysed by the determination of BDP in tablets. The results obtained are satisfactory with the excellent \% recovery and $\mathrm{SD}<2$ (Table 3). Experiments showed that there was no interference due to the additions and excipients.

Table 3. The results of BDP in tablets using proposed fluorimetric technique $(n=5)$.

\begin{tabular}{cccc}
\hline $\begin{array}{c}\text { Label claim } \\
(\mathrm{mg} / \text { per tablet })\end{array}$ & Mean $^{\mathrm{b}} \pm$ S.D & Recovery $(\%)$ & RSD (\%) \\
\hline 4 & $4.03 \pm 0.027$ & 100.75 & 0.68 \\
\hline a Coniel ${ }^{\circledR}(4 \mathrm{mg})$ & & \\
b Five independent analyses. & & & \\
\end{tabular}

The analysis were trialed as described the general analysis procedure to understand for applicability of the proposed method to spiked plasma samples. The results were shown in Table 4 which has precise and accurate.

Table 4. The results of recoveries of BDP using plasma samples $(n=5)$.

\begin{tabular}{cccc}
\hline $\begin{array}{c}\text { Added } \\
\left(\mathrm{ng} \mathrm{mL}^{-1}\right)\end{array}$ & $\begin{array}{c}\text { Determined } \pm \text { S.D } \\
\left(\mathrm{ng} \mathrm{mL}^{-1}\right)\end{array}$ & $\begin{array}{c}\text { Recovery } \\
(\%)\end{array}$ & $\begin{array}{c}\text { RSD } \\
(\%)^{\mathrm{a}}\end{array}$ \\
\hline 20.0 & $14.52 \pm 0.12$ & 72.60 & 0.83 \\
100.0 & $78.26 \pm 0.54$ & 78.26 & 0.69 \\
200.0 & $168.37 \pm 0.89$ & 84.18 & 0.53 \\
\hline
\end{tabular}

a Five independent analyses.

\section{CONCLUSION}

The proposed fluorimetric technique has high sensitivities and simple analytical process in order to analysis of BDP in bulk, tablet formulations and spiked plasma. Therefore, the proposed technique is suggestible for a routine quality control and clinical laboratories.

\section{MATERIALS AND METHODS}

\subsection{Materials}

\subsubsection{Solutions}

Benidipine was kindly supplied by Pure Chem LTD (Gujarat, India) and its tablets (Coniel $\left.{ }^{\circledR}\right)$ was taken from local drugstore. NBD- F and other chemicals were from Fluka. Analytical grade chemicals were used. benidipine stock solution was prepared as $1 \mathrm{mg} \mathrm{mL}^{-1}$ in methanol and dilution were made with the same solvent $\left(5 \mu \mathrm{g} \mathrm{mL}^{-1}\right)$. Methanol was used for preparing NBD-F solution (0.5\% solution). Buffer solution were prepared as follow: $0.375 \mathrm{~g}$ potassium chloride and $0.310 \mathrm{~g}$ of boric acid were weighed and $50 \mathrm{~mL}$ of water was added. The $\mathrm{pH}$ was brought to 8.0 using $0.1 \mathrm{~N}$ sodium hydroxide solutions.

\subsubsection{Apparatus}

Hitachi spectrofluorometer (Model U-2900) were used forf luorescence measurements Xenon lamps and $1 \mathrm{~cm}$ light path cells were used. The excitation wavelength was $465 \mathrm{~nm}$ and emission wavelength was of 550 $\mathrm{nm}$. The $\mathrm{pH}$ was measures using the WTW $\mathrm{pH} 526$ digital $\mathrm{pH}$ meter. (The sensitivity of the $\mathrm{pH}$ meter is: $-2.00-$ $16.00 \mathrm{pH}$, accuracy: 0.01 at room temperature. $\mathrm{pH}$ meter has been calibrated using calibration buffers have $\mathrm{pH}$ of $4.01,7.00$.) 


\subsection{Methods}

\subsubsection{General procedures}

0.010-0.2 mL standard series of BDP solutions has been added to $10 \mathrm{~mL}$ tubes. These solution has been diluted with methanol to $0.2 \mathrm{~mL}$ and mixed with $0.2 \mathrm{~mL}$ of borate solution. After addition of $0.2 \mathrm{~mL}$ NBD-F solution, the system was heated at $80^{\circ} \mathrm{C}$ for $3 \mathrm{~min}$. The cooling was done in the ice batch and then mixture was acidified using $0.2 \mathrm{~mL}$ of $1 \mathrm{~N} \mathrm{HCl}$ solutions. The extraction was made with $5 \mathrm{~mL}$ of dichloromethane on a vortex mixer and centrifugated. The fluorescence intensities were measured against a blank prepared similarly ( $\lambda_{\text {ex }}: 465 \mathrm{~nm}$ and $\lambda_{\text {em }}: 550 \mathrm{~nm}$ ). Sodium fluorescein was used as a reference standart solution.

\subsubsection{Procedure for tablet formulation}

Ten tablets were taken into $250 \mathrm{~mL}$ volumetric flask. After addition of $200 \mathrm{~mL}$ of methanol, the content was mixed 20 minutes mechanically and sonicated for 20 minutes. The volume of flask was completed to 250 $\mathrm{mL}$ with water. The $20 \mathrm{~mL}$ of the filtrate was removed. This filtrate was further diluted using methanol to get working solutions then processed as detailed under the preparation of calibration curve. The nominal contents of the tablets were determined using the calibration graph.

\subsubsection{Procedures for plasma samples}

$5.0 \mathrm{~mL}$ of human blood sample has been used and the sample has been centrifuged at $3000 \mathrm{rpm}$ for 30 min. (Ethics committee approval was taken by BVU Ethics Clinical Research Commite, number: 13/02/20192792). A $100 \mu \mathrm{L}$ of plasma samples has been spiked with three different concentration $(20,100$ and $200 \mathrm{ng} \mathrm{mL}-$ 1) of drug and added $1 \mathrm{~mL}$ of $5 \mathrm{~N} \mathrm{NaOH}$ followed by 1-min liquid-liquid extraction with $5 \mathrm{~mL}$ of diethyl ether [10]. The organic layer was evaporated through evaporated to dryness under nitrogen at room temperature. After adding $100 \mu \mathrm{l}$ methanol to residue, method was performed according to described in Section 2. was followed and measured the fluorescence of solution ( $\lambda_{\text {ex }}: 465 \mathrm{~nm}$ and $\lambda_{\text {em }}: 550 \mathrm{~nm}$ ). Measurement in the plasma were done a previously plotted calibration graph and using the corresponding regression equation.

Author contributions: Concept - C.Ö., Ş.E.K.T.; Design - C.Ö., Ş.E.K.T.; Supervision - C.Ö., Ş.E.K.T.; Materials - C.Ö., Ş.E.K.T.; Data Collection and/or Processing - C.Ö., Ş.E.K.T.; Analysis and/or Interpretation - C.Ö., Ş.E.K.T.; Literature Search - C.Ö., Ş.E.K.T.; Writing - C.Ö., Ş.E.K.T.; Critical Reviews - C.Ö., Ş.E.K.T.

Conflict of interest statement: The authors declared no conflict of interest in the manuscript.

\section{REFERENCES}

[1] Karasawa A, Kubo K, Oka T, Nakamizo N. Antihypertensive effects of the new calcium antagonist benidipine hydrochloride in rats. Arzneimittelforschung. 1988; 38(11A): 1684-1690.

[2] Kobayashi H, Kobayashi S. Enantiomer-enantiomer interaction of a calcium channel antagonist, benidipine hydrochloride, during liver metabolism in the rat. Eur J Drug Metab Pharmacokinet. 1999; 24(2): 121-126. [CrossRef]

[3] Kobayashi H, Kobayashi S. Relationship between plasma concentration and antihypertensive effects of the dihydropyridine calcium antagonist, benidipine, in rats. J Pharm Pharmacol. 1997; 49(12): 1200-1204. [CrossRef]

[4] Maier-Lenz H, Rode H, Lenau H, Thieme G, Wölke E, Kobayashi H, Kobayashi S, Oka T. Benidipine hydrochloride: a new calcium-channel blocker of the dihydropyridine type. Arzneimittelforschung. 1988; 38(11A): 1757-1763.

[5] Karasakal A. First order derivative spectrophotometric method for the determination of benidipine hydrochloride pharmaceutical preparations and forced degradation study. Opt Spectrosc. 2015; 118: 1002-1006. [CrossRef]

[6] Karadas N, Sanli S, Gumustas M, Ozkan SA. Voltammetric and RP-LC assay for determination of benidipine HCl. J Pharm Biomed Anal. 2012; 66: 116-25. [CrossRef]

[7] Uji Y, Sugimoto T, Kobayashi S, Kobayashi H. Phase I clinical study of benidipine hydrochloride. Jpn Pharmacol Ther. 1990; 18; 7-20.

[8] Kobayashi H, Okumura S, Kosaka Y, Kobayashi S, Inoue A, Oka T, Nakamizo N. Identification of benidipine hydrochloride metabolites in rats and dogs, ArzneimittelForschung/Drug Res. 1988; 38: 1753-1756. 
[9] Magara H, Kobayashi H, Kobayashi S. Determination of benidipine in human plasma by capillary column gas chromatography-negative chemical ionization mass spectrophotometry. J Chromatogr B. 1993; 617(1): 59-63. [CrossRef]

[10] Kang W, Lee DJ, Liu KH, Sunwoo YE, Kwon KI, Cha IJ, Shin JG. Analysis of benidipine enantiomers in human plasma by liquid chromatography-mass spectrometry using a macrocyclic antibiotic (vancomycin) chiral stationary phase column, J. Chromatogr. B. 2004; 805: 75-81.

[11] Toyo'oka T, Watanabe Y, Imai K. Reaction of amines of biological importance with 4-fluoro-7-nitrobenzo-2-oxa-1,3diazole. Anal Chim Acta. 1983; 149: 305-312. [CrossRef]

[12] Job P. Formation and Stability of Inorganic Complexes in Solution. Anal Chim. 1928; 9: 113-203.

[13] ICH, “Q2 (R1) Validation of Analytical Procedures: Text and Methodology," International Conference on Harmonization, Geneva, November 2005, pp. 1-13.

This is an open access article which is publicly available on our journal's website under Institutional Repository at http://dspace.marmara.edu.tr. 